\title{
Alergeno sukelto lokalaus ir sisteminio imuninio atsako žymenų bei gyvenimo kokybės sąsajų vertinimas sergant alerginiu rinitu
}

\author{
THE RELATION BETWEEN ALLERGEN-INDUCED LOCAL AND SYSTEMIC IMMUNE \\ RESPONSE AND QUALITY OF LIFE IN PATIENTS WITH ALLERGIC RHINITIS
}

\author{
AUGUSTÉ RAGELYTÉ ${ }^{1}$, RUSNĖ GLINSKYTE் ${ }^{1}$, BRIGITA ŠITKAUSKIENÉ2, EDITA GASIÜNIENË² \\ ${ }^{1}$ LSMU MA Medicinos fakultetas, ${ }^{2}$ LSMU MA Imunologijos ir alergologijos klinika
}

\begin{abstract}
Santrauka. Alerginis rinitas (AR) - tai dažna alerginè liga, sutrikdanti sergančiųjų gyvenimo kokybę. Klinikinèje praktikoje sergantiesiems AR dažnai atliekami imuninio atsako tyrimai (bendrojo imunoglobulino E (IgE) kieko kraujyje, eozinofilu kiekio kraujyje ir nosies sekrete nustatymas), bet jų ryšys su pacientų gyvenimo kokybe plačiau nebuvo tirtas. Tyrimo tikslas. Nustatyti sergančiųjų AR vietinio ir sisteminio imuninio atsako savitumus bei sąsajas su jų gyvenimo kokybe. Metodai. Ištirti 52 pacientai, sergantys AR, kurie buvo konsultuoti Lietuvos sveikatos mokslų universiteto ligoninès Kauno klinikų (toliau - Kauno klinikos) Imunologijos ir alergologijos klinikoje ir užpildè gyvenimo kokybės klausimyną (RQLQ(S)), taip pat iš medicininių dokumentų rinkti duomenys apie tiriamųjų amžių, lytį, alerginio rinito tipą, eozinofilų kiekį nosies sekrete bei

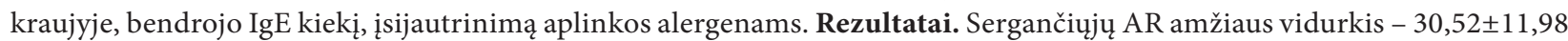
metų, bendros gyvenimo kokybès mediana - 1,57 (0-4,64); nenustatyta sąsajų tarp bendros gyvenimo kokybès ir eozinofilų kiekio nosies sekrete $(\mathrm{r}=0,111, \mathrm{p}=0,449)$, eozinofilų kraujyje, proc. $(\mathrm{r}=0,210, \mathrm{p}=0,162)$, kraujo eozinofilų, $\times 10^{9} / 1$ $(\mathrm{r}=0,219, \mathrm{p}=0,143)$, bendrojo IgE $(\mathrm{r}=0,206, \mathrm{p}=0,165)$. Gyvenimo kokybès klausimyno rezultatai, vertinti atsižvelgiant ị lytị, nesiskyrè, išskyrus praktines problemas, kurios labiau vargino moteris $(2(0-5,67)$, palyginus su $0,67(0-4), p=0,033)$. Tiriamųjų, įsijautrinusių naminių gyvūnų alergenams, miego kokybė buvo blogesnè (1,5 (0-6), palyginus su 0,33 (0-3,33), $\mathrm{p}=0,036)$, o i̇sijautrinusių maisto alergenams - didesni bendrojo IgE rezultatai $(398,65(42,4-1382,7)$, palyginus su 127,55 (3-1899,3), p = 0,019). Išvados. Gyvenimo kokybė nepriklausè nei nuo vietinio arba sisteminio imuninio atsako raiškos, nei nuo AR tipo. Praktinès problemos, susijusios su AR, labiau vargino moteris nei vyrus. Tiriamiesiems, kurie buvo įsijautrinę naminių gyvūnų alergenams, labiau sutriko miego kokybė, ịsijautrinusiems maisto produktams, sisteminè imuninio atsako raiška buvo didesnè.
\end{abstract}

Reikšminiai žodžiai: alerginis rinitas, gyvenimo kokybè.

Summary. Allergic rhinitis (AR) is a common allergic disease. It strongly affects the patients' life quality. Although laboratory tests evaluating immune response are often performed for patients with AR in clinical practice, there is no much data analyzing their link to the quality of life. Objective. To evaluate the local and systemic immune response and its correlation with the quality of life in patients with AR. Methods. 52 randomly selected AR patients who were treated at the Hospital of Lithuanian University of Health Sciences Kauno klinikos filled in Rhinoconjunctivitis Quality of Life Questionnaire (RQLQ(S)) and additional data was collected (eosinophils in nasal smear and peripheral blood, total serum immunoglobulin E (IgE), allergens, sex, age, AR type). Results. 38.5\% were men and 61.5\% - women. Average patients' age was $30.52 \pm 11.98$ years. Total life quality median was $1.57(0-4.64)$. There was no significant correlation between total quality of life and the number of eosinophiles in nasal smear $(\mathrm{r}=0.111, \mathrm{p}=0.449)$, peripheral blood, $\%(\mathrm{r}=0.210, \mathrm{p}=0.162)$, peripheral blood, $\times 10^{9} / 1(\mathrm{r}=0.219, \mathrm{p}=0.143)$, total serum $\operatorname{IgE}(\mathrm{r} 0.206, \mathrm{p}=0.165)$. The life quality was the same for men and women, except for the practical problems that were more exhausting for the women $(2(0-5.67) v s .0 .67(0-4), \mathrm{p}=0.033)$. Sensitivity to pets' allergens was related to poorer quality of sleep $(1.5(0-6) v s .0 .33(0-3.33), \mathrm{p}=0.036)$; sensitivity to food allergens was associated with higher serum total IgE (398.65 (42.4-1382.7) vs. 127.55 (3-1899.3), $\mathrm{p}=0.019)$. Conclusion. The life quality was not related to the local and systemic immune response or AR type. AR-induced practical problems were more frequent in women than in men. The quality of sleep was lower in patients sensitive to pets' allergens, and total serum IgE was higher for those with sensitivity to food allergens.

Keywords: allergic rhinitis, quality of life. 


\section{Moksliniai darbai ir apžvalgos}

\section{IVADAS}

Alerginis rinitas (AR) - tai viena dažniausių alerginių ligų [1]. Tai didelè sveikatos problema, paplitusi visame pasaulyje. Sergamumas šia liga išsivysčiusiose šalyse (JAV, Vakarų Europos šalyse ir kt.) siekia nuo 10 iki 30 proc. [1]. AR būdingi čiaudulio, rinorèjos ir nosies užburkimo epizodai, dažnai kartu gali pasireikšti akių, nosies ir gomurio niežulys, ašarojimas arba akių deginimas [2]. Nepaisant plataus gydymo galimybių pasirinkimo, pacientus neretai vargina pablogejusi gyvenimo kokybè, AR simptomai, kurie pasireiškia nepakankamai arba netinkamai gydant [3]. Pastebèta, kad AR simptomai neigiamai veikia kasdienę žmogaus veiklą: sumažina darbingumą, sunkina mokymosi procesą, trukdo laisvalaikiui, poilsiui. Neretai pacientai patiria miego sutrikimų, tampa emociškai labilūs (pasireiškia nerimas, depresija), sumažeja seksualinis aktyvumas [4]. Nosies užgulimas ypač susijęs su miego sutrikimais - sergantieji AR žymiai dažniau skundžiasi pablogèjusiu miegu (60-75 proc.) nei sveiki (8-18 proc.) asmenys, todèl sutrinka mokymasis, dèmesio koncentracija, prastėja psichinè sveikata [5-8]. Atliktos apklausos duomenimis, vidutiniškai 20 proc. sergančiụjų AR teigè, kad AR simptomai daro neigiamą ittaką darbo produktyvumui [9]. Lyginamieji tyrimai parodè, kad AR simptomai mažina darbo našumą labiau nei arterinè hipertenzija ir 2 tipo cukrinis diabetas [10]. Todèl, siekiant gerinti sergančiųjų AR gyvenimo kokybę, aktualūs išlieka šių pacientų gyvenimo kokybę nagrinejjantys moksliniai tyrimai. Žinoma, kad laboratorinių tyrimų, rodančių sisteminę, alergeno sukeltą imuninę reakciją, duomenys nèra labai svarbūs AR diagnostikai bei AR sunkumui ivertinti [11], tačiau šie tyrimai klinikinejje praktikoje atliekami dažnai, o jų ryšys su pacientų gyvenimo kokybe plačiai netyrinètas.

Šio tyrimo tikslas - nustatyti sergančiujjų AR vietinio ir sisteminio imuninio atsako savitumus bei sąsajas su pacientų gyvenimo kokybe.

\section{TYRIMO MEDŽIAGA IR METODAI}

Tyrime dalyvavo vyresni nei 18 metu asmenys, sergantys AR (AR diagnozuotas remiantis pacientu išsakytais simptomais, tokiais kaip priepuolinis čiaudulys, rinoreja, užsikimšusi nosis, niežtinti nosis, nosies sekreto tekejjimas ị gerklę, akių simptomai, bei atliktais odos dūrio mėginiais), kurie pirmą kartą kreipèsi i Lietuvos sveikatos mokslų universiteto ligoninès Kauno klinikų (toliau - Kauno klinikos) Imunologijos ir alergologijos kliniką. Tiriamųjų anketinè apklausa vykdyta nuo 20171001 iki 201805 01. Tyrimo dalyviai atrinkti atsitiktine tvarka. Tyrimui vykdyti gautas Lietuvos sveikatos mokslų universiteto Bioetikos centro pritarimas Nr. BEC-MF-31. Tyrimas vykdytas tik informavus pacientą ir gavus raštišką jo sutikimą.
Tiriamieji pildè standartizuotą, Lietuvai pritaikytą AR sergančiojo gyvenimo kokybès klausimyną (angl. Rhinoconjunctivitis Quality of Life Questionnaire, RQLQ(S)) lietuvių kalba. Leidimas naudoti šį klausimyną ir jo naudojimo metodikos gautos iš klausimyno autorès profesorès Elizabeth F. Juniper (McMaster universitetas, Kanada). Klausimyno validavimas atliktas 2013 m. Daivos Dijokevičienès (MAPI institute). Klausimyną sudare 28 klausimai, suskirstyti $\mathfrak{i}$ septynias sritis (veiklos rūšis, miegas, bendrieji simptomai, praktinès problemos, nosies simptomai, akių simptomai, emocijos). Siekta išsiaiškinti AR simptomų intensyvumą bei įvertinti sergančiųjų gyvenimo kokybę. Pacientų buvo prašoma atsakyti ị visus klausimus, apibraukiant tą skaičių, kuris geriausiai apibūdina, kaip intensyviai praejjusią savaitę juos vargino minèti simptomai, vertinant 7 balų skaleje ( 0 - simptomai nevargino, 1 - beveik nevargino, 2 - šiek tiek vargino, 3 - vidutiniškai vargino, 4 - gerokai vargino, 5 - labai vargino, 6 - ypač vargino). Bendrasis gyvenimo kokybès balas iqvertintas apskaičiavus visos anketos atsakymų vidurkị. Siekiant ịvertinti imuninio atsako raišką, analizuoti tiriamiesiems ịprastai ambulatorinèje praktikoje atliekami tyrimai: bendrasis kraujo tyrimas bei nosies sekreto citologinis tyrimas eozinofilu kiekiui ịvertinti, imunoglobulino (Ig) E kiekis kraujo serume. Kartu buvo renkami duomenys apie tiriamujų ìsijautrinimą aplinkos alergenams (pagal odos dūrio méginio ir specifinių IgE kraujyje tyrimo rezultatus), kita informacija (demografiniai duomenys: lytis, amžius, AR tipas, kt.). Tiriamieji suskirstyti i grupes pagal AR tipą (remiantis Amerikos alergijos, astmos ir imunologijos akademijos (angl. American Academy of Allergy Asthma and Immunology, AAAAI) rekomendacijomis): sergantieji nuolatiniu AR (55,8 proc.) ir epizodiniu AR (32,7 proc.).

Gauti duomenys susisteminti ir analizuoti naudojant Microsoft Excel 2007 ir SPSS 22.0 programinius paketus. Dažnis pateikiamas absoliučiaisiais skaičiais (n) ir procentais (proc.). Kiekybiniai duomenys pateikiami kaip vidurkis ir standartinis nuokrypis bei mediana ir minimumo-maksimumo (min.-maks.) reikšmèmis. Normaliojo skirstinio grupès tarpusavyje lygintos naudojant Stjudento (t) kriterijų nepriklausomoms imtims. Dviejų kiekybinių dydžių koreliacijai vertinti, kai duomenys tenkino normalumo sąlygą, taikytas Pirsono koreliacijos koeficientas, o kai jos netenkino - Spirmeno koreliacijos koeficientas. Vertinant požymio pasiskirstymo populiacijose skirtumus (duomenims netenkinant normalumo sąlygos), taikytas Kruskalio-Voliso kriterijus nepriklausomoms imtims. Kelių nepriklausomų imčių, atitinkančių normalųji skirstinį, vidurkiai lyginti naudojant vienfaktorinę dispersinę analizę ANOVA. Duomenys vertinti kaip statistiškai reikšmingi, kai p<0,05. 


\section{Moksliniai darbai ir apžvalgos}

\section{REZULTATAI}

Iš 52 tyrime dalyvavusių sergančiujų AR 20 (38,5 proc.) buvo vyrai ir 32 (61,5 proc.) moterys. Pacientų amžiaus vidurkis $-30,52 \pm 11,98$ metų. 55,8 proc. tyrimo dalyvių sirgo nuolatiniu AR, 32,7 proc. - sezoniniu, likusiems 11,5 proc. AR tipas tyrimo metu nebuvo patikslintas. İvertinus įsijautrinimą alergenams (1 lentelè) ir ryši su gyvenimo kokybe, nustatyta, kad isijautrinusieji naminiu gyvūnų alergenams nurodè prastesnę miego kokybę nei neįsijautrinusieji $(1,5(0-6)$, palyginus su $0,33(0-3,33)$, $\mathrm{p}=0,036)$. Kitų reikšmingų sąsajų nerasta.

Vertinant sąsajas tarp alergenų, kuriems nustatytas įsijautrinimas, ir imuninio atsako žymenų, nustatyta, kad pacientams, kurie buvo įsijautrinę maisto alergenams, sisteminè imuninio atsako raiška (vertinant bendrajji IgE) buvo didesnè $(398,65$ (42,4-1382,7), palyginti su 127,55 (3-1899,3), $\mathrm{p}=0,019)$. Analizuotuc laboratorinių tyrimų rezultatai pateikiami 2 lenteleje.

Vertinant pacientų gyvenimo kokybę pagal RQLQ(S) anketos autorių rekomendacijas [12], apskaičiuotos tiriamųjų pažymėtų balų vidutinès reikšmės kiekvienoje iš anketos dalių ( 3 lentelè). Taip pat tyrimo dalyviai suskirstyti i grupes pagal lytị bei lyginti RQLQ(S) rezultatai šiose grupése.

1 lentelè. Tiriamujų įsijautrinimo ịvairiems alergenams pasiskirstymas

\begin{tabular}{|l|c|}
\hline \multicolumn{1}{|c|}{ Alergenai } & Dažnis, $\mathbf{n}$ (proc.) \\
\hline Namų dulkių erkių & $29(55,8)$ \\
\hline Naminių gyvūnų & $30(57,7)$ \\
\hline Žiedadulkiụ & $49(94,2)$ \\
Medžių & $22(42,3)$ \\
Žoliụ & $20(38,4)$ \\
Piktžolių & $7(13,5)$ \\
\hline Maisto & $16(30,8)$ \\
\hline
\end{tabular}

Reikšmingų sąsajų tarp bendrojo gyvenimo kokybès balo ir eozinofilu kiekio nosies sekrete $(r=0,111$, $p=0,449)$, eozinofilų kiekio kraujyje, proc. $(r=0,210$, $\mathrm{p}=0,162)$, eozinofilų kiekio kraujyje, vertinant absoliučiaisiais skaičiais $\times 10^{9} / 1(\mathrm{r}=0,219, \mathrm{p}=0,143)$, bendrojo IgE kiekio kraujyje $(r=0,206, p=0,165)$ nerasta. Analizuota ir skirtingu gyvenimo kokybès klausimyno dalių rezultatų koreliacija su minètais rodikliais. Analizès duomenys pateikiami 4 lenteleje. Vertinta sergančiųjų AR gyvenimo kokybė atsižvelgiant ị AR tipą (5 lentelè).

\section{REZULTATŲ APTARIMAS}

Šis tyrimas parode, kad objektyvi alergeno sukelto imuninio atsako raiška nèra esminis veiksnys, lemiantis sergančiųų AR gyvenimo kokybę. Taip pat nenustatyta sąsajų tarp gyvenimo kokybès ir rinito tipo. Simptomų bei jų itakos gyvenimo kokybei vertinimas yra subjektyvus ir priklauso nuo įvairių veiksnių, ne vien nuo ligos sunkumo, todèl sergančiųjų AR gydymas turi būti individualizuotas ir pritaikytas vadovaujantis ne tiek tyrimų rezultatais, kiek paciento skundais, pasitelkiant ir gyvenimo kokybės klausimynus.

$\mathrm{RQLQ}(\mathrm{S})$ yra vienas iš klausimynų, naudojamų ser-

2 lentelè. Sergančiujų alerginiu rinitu kraujo ir nosies sekreto citologinio tyrimo rezultatai

\begin{tabular}{|l|c|}
\hline & Mediana (min.-maks.) \\
\hline $\begin{array}{l}\text { Eozinofilų skaičius nosies } \\
\text { sekrete, proc. }\end{array}$ & $0(0-90)$ \\
\hline $\begin{array}{l}\text { Eozinofilų skaičius kraujyje, } \\
\times 10^{9} / \mathrm{I}\end{array}$ & $0,26(0,04-0,8)$ \\
\hline $\begin{array}{l}\text { Eozinofilų skaičius kraujyje, } \\
\text { proc. }\end{array}$ & $4(0,6-11,2)$ \\
\hline IgE kraujo serume, kU/I & $211,1(3-1899,3)$ \\
\hline
\end{tabular}

3 lentelè. Sergančiujų alerginiu rinitu gyvenimo kokybès ịvertinimas pagal RQLQ(S) rezultatus

\begin{tabular}{|l|c|c|c|c|}
\hline & $\begin{array}{c}\text { Mediana } \\
\text { (min.-maks.) }\end{array}$ & $\begin{array}{c}\text { Moterų rezultatų mediana } \\
\text { (min.-maks.) }\end{array}$ & $\begin{array}{c}\text { Vyrų rezultatų mediana } \\
\text { (min.-maks.) }\end{array}$ & p reikšmé \\
\hline Ivairi veikla & $2(0-5,33)$ & $2,33(0-5,33)$ & $1,83(0-3,33)$ & 0,151 \\
\hline Miegas & $1,33(0-6)$ & $1,5(0-6)$ & $1(0-5)$ & 0,441 \\
\hline Bendrieji simptomai & $1,29(0-4)$ & $1,21(0-4)$ & $1,5(0-3,71)$ & 0,295 \\
\hline Praktinės problemos & $1,67(0-5,67)$ & $2(0-5,67)$ & $0,67(0-4)$ & 0,033 \\
\hline Nosies simptomai & $2(0-4,5)$ & $1,88(0-4,5)$ & $2(0,25-3,75)$ & 0,992 \\
\hline Akiu simptomai & $0,63(0-5,25)$ & $0,88(0-5,25)$ & $0,38(0-2,75)$ & 0,273 \\
\hline Emocijos & $1,63(0-5)$ & $1,63(0-5)$ & $1,75(0-4,25)$ & 0,857 \\
\hline Bendroji gyvenimo kokybė & $1,57(0-4,64)$ & $1,57(0-4,64)$ & $1,37(0,18-2,82)$ & 0,579 \\
\hline
\end{tabular}




\section{Moksliniai darbai ir apžvalgos}

4 lentelè. Sergančiujų alerginiu rinitu gyvenimo kokybės ir imuninio atsako žymenų ryšio vertinimas

\begin{tabular}{|c|c|c|c|c|}
\hline & $\begin{array}{c}\text { Eozinofilai (proc.) } \\
\text { nosies sekrete }\end{array}$ & $\begin{array}{c}\text { Eozinofilai (proc.) } \\
\text { kraujyje }\end{array}$ & $\begin{array}{c}\text { Eozinofilai }\left(\times 10^{9} / \mathrm{l}\right) \\
\text { kraujyje }\end{array}$ & $\begin{array}{c}\text { IgE kraujo serume } \\
\text { (kU/l) }\end{array}$ \\
\hline Ivairi veikla & $\begin{array}{l}r=0,026 \\
p=0,858\end{array}$ & $\begin{array}{l}r=0,169 \\
p=0,262\end{array}$ & $\begin{array}{l}r=0,204 \\
p=0,175\end{array}$ & $\begin{array}{l}r=-0,110 \\
p=0,461\end{array}$ \\
\hline Miegas & $\begin{array}{l}r=0,010 \\
p=0,946\end{array}$ & $\begin{array}{l}r=0,153 \\
p=0,311\end{array}$ & $\begin{array}{l}r=-0,017 \\
p=0,910\end{array}$ & $\begin{array}{l}r=-0,220 \\
p=0,137\end{array}$ \\
\hline Bendrieji simptomai & $\begin{array}{l}r=-0,099 \\
p=0,496\end{array}$ & $\begin{array}{l}r=0,190 \\
p=0,206\end{array}$ & $\begin{array}{l}r=0,267 \\
p=0,072\end{array}$ & $\begin{array}{l}r=-0,235 \\
p=0,111\end{array}$ \\
\hline Praktinès problemos & $\begin{array}{l}r=-0,048 \\
p=0,746\end{array}$ & $\begin{array}{l}r=0,156 \\
p=0,302\end{array}$ & $\begin{array}{l}r=0,085 \\
p=0,574\end{array}$ & $\begin{array}{l}r=-0,240 \\
p=0,149\end{array}$ \\
\hline Nosies simptomai & $\begin{array}{l}r=-0,019 \\
p=0,895\end{array}$ & $\begin{array}{l}r=0,100 \\
p=0,508\end{array}$ & $\begin{array}{l}r=0,152 \\
p=0,314\end{array}$ & $\begin{array}{l}r=-0,217 \\
p=0,143\end{array}$ \\
\hline Akių simptomai & $\begin{array}{l}r=0,041 \\
p=0,782\end{array}$ & $\begin{array}{l}r=0,229 \\
p=0,126\end{array}$ & $\begin{array}{l}r=0,265 \\
p=0,076\end{array}$ & $\begin{array}{l}r=-0,006 \\
p=0,967\end{array}$ \\
\hline Emocijos & $\begin{array}{l}r=-0,214 \\
p=0,139\end{array}$ & $\begin{array}{l}r=0,084 \\
p=0,577\end{array}$ & $\begin{array}{l}r=0,109 \\
p=0,469\end{array}$ & $\begin{array}{l}r=-0,263 \\
p=0,074\end{array}$ \\
\hline
\end{tabular}

5 lentelè. Gyvenimo kokybès savitumų palyginimas skirtingiems alerginiu rinitu tipams

\begin{tabular}{|l|c|c|c|c|}
\hline & $\begin{array}{c}\text { Nuolatinis AR } \\
\text { Mediana (min.-maks.) }\end{array}$ & $\begin{array}{c}\text { Sezoninis AR } \\
\text { Mediana (min.-maks.) }\end{array}$ & $\begin{array}{c}\text { Nepatikslintas AR } \\
\text { Mediana (min.-maks.) }\end{array}$ & p reikšmé \\
\hline lvairi veikla & $2(0-5,33)$ & $2(0-3,67)$ & $2,17(0,67-4,33)$ & 0,660 \\
\hline Miegas & $1,67(0-6)$ & $0,33(0-3,67)$ & $1,5(0,67-3,33)$ & 0,219 \\
\hline Bendrieji simptomai & $1,29(0-4)$ & $1,29(0-2,86)$ & $2,07(0-3,57)$ & 0,347 \\
\hline Praktinės problemos & $2(0-5,67)$ & $1(0-4,33)$ & $0,83(0-4)$ & 0,537 \\
\hline Nosies simptomai & $2,25(0,25-4,5)$ & $1,5(0-4)$ & $1,38(0,5-2)$ & 0,230 \\
\hline Akių simptomai & $0,75(0-5,25)$ & $0,25(0-4,5)$ & $0,63(0-2)$ & 0,866 \\
\hline Emocijos & $1,75(0-5)$ & $0,5(0-4,25)$ & $1,75(0-4,5)$ & 0,666 \\
\hline Bendroji gyvenimo kokybe & $1,61(0,04-4,64)$ & $1,14(0-3,18)$ & $1,64(0,54-2,96)$ & 0,730 \\
\hline
\end{tabular}

$\mathrm{AR}$ - alerginis rinitas.

gančiųjų AR gyvenimo kokybei ịvertinti. Pasak autorių, klinikinejje praktikoje šio klausimyno rezultatai turètų būti interpretuojami lyginant atsakymų rezultatus skirtingų konsultacijų metu: įrodyta, jog reikšmingas yra 0,5 balo pokytis, kuriam esant, AR gydymas turètu būti atitinkamai koreguojamas [12]. Taip pat RQLQ(S) plačiai naudojamas ịvairiuose klinikiniuose tyrimuose.

Pasitelkę RQLQ(S), Axelsson su bendraautoriais nustate, kad gyvenimo kokybe், sergant AR, skiriasi tarp vyrų ir moterų, taip pat reikšmingos yra asmenybès savybės [13]. Mūsų atlikto tyrimo dalyvių gyvenimo kokybės analizė pagal lyti parodé, kad tik praktinès problemos (nepatogumas, kad reikia nuolat nešiotis popierinių servetèlių, poreikis nuolat trinti akis/nosį, poreikis nuolat pūsti nosị) labiau vargina moteris nei vyrus. Tiriamųjų buvo klausiama, kaip labai juos vargino minètos problemos, o ne kaip dažnai jos pasireiškè, todèl galima daryti prielaidą, kad vyrai dèl asmeninių savybių šias problemas subjektyviai vertina kaip mažiau reikšmingas.

Klinikiniuose tyrimuose pastebèta, kad sergančiųjų AR gyvenimo kokybė priklauso nuo įsijautrinimo ìvairiems alergenams, pvz., Li ir bendraautoriai nustatè, jog asmenų, i̦sijautrinusių žiedadulkių ir namų dulkių erkių alergenams, gyvenimo kokybè prastesnè [14]. Šio tyrimo metu nustatyta, kad pacientų, įsijautrinusių naminių gyvūnų alergenams, miego kokybė buvo žymiai blogesnè. Žinoma, kad miego sutrikimai, sergant AR, yra labai reikšmingi: Meltzer ir kiti nustatè, kad jie lemia darbo produktyvumo mažèjimą, Koinis-Mitchell su bendraautoriais pabrěžè šių sutrikimų gydymo reikšmę gerinant pacientų savijautą ir gyvenimo kokybę $[15,16]$. Taigi, sergantiesiems AR ir įsijautrinusiems naminių gyvūnų alergenams, ypač svarbu paaiškinti 


\section{Moksliniai darbai ir apžvalgos}

apie alergenų vengimo svarbą, išsiaiškinti miego sutrikimus bei skirti veiksmingą gydymą.

Vertinant atlikto tyrimo rezultatus, reikia atsižvelgti ¡̣ kai kuriuos apribojimus. Dẻl ribotų išteklių tiriamųjų imtis gana maža. Be to, gyvenimo kokybès vertinimas, netgi pildant standartizuotus klausimynus, išlieka subjektyvus: rezultatai galejo būti veikiami tokių veiksnių, kaip tiriamujuc gretutinès ligos, vartojami vaistai, išsilavinimas ir kt. Taip pat vertinti standartinių tyrimų imuninio atsako žymenų rezultatai. Yra duomenų apie kitus žymenis, rodančius alergeno sukeltos imuninès reakcijos intensyvumą, pvz., Izuhara su bendraautoriais įrodé, jog, sergant alerginėmis ligomis, padidejo periostino koncentracija ir kad jis galètų būti naudojamas kaip diagnostinis žymuo [17]. Sha su bendraautoriais nustatè, jog sergančiųjų AR $\beta$-endorfino koncentracija yra mažesnè nei sveiku savanorių, o mažejjant $\beta$-endorfino koncentracijai, blogèja ir gyvenimo kokybė [18]. Wang ir kiti aptiko padidejjusią sergančiųjų AR kraujo IL-19 koncentraciją bei ryši su gyvenimo kokybe [19]. Taigi, siekiant ịvertinti alergeno sukelto imuninio atsako raišką ir sąsają su pacientų gyvenimo kokybe, sergant AR, reikia atlikti didesnès imties bei platesnị imuninio atsako žymenu spektrą analizuojančius tyrimus.

\section{IŠVADOS}

Pacientų, sergančių AR, gyvenimo kokybė nepriklausè nuo vietinio arba sisteminio imuninio atsako žymenų ir nuo AR tipo. Praktinès problemos, susijusios su AR, labiau vargino moteris nei vyrus. Tiriamiesiems, kurie buvo ịsijautrinę naminių gyvūnų alergenams, labiau nei įsijautrinusiems kitiems alergenams, sutriko gyvenimo kokybé, susijusi su miegu. Tyrimo dalyviams, ịsijautrinusiems maisto alergenams, nustatyta didesnè IgE koncentracija kraujyje.

Gauta: 20190301

Priimta: 20190410

\section{LITERATŪRA}

1. Ozdoganoglu T, Songu M, Inancli HM. Quality of life in allergic rhinitis. Ther Adv Respir Dis. 2012; 6(1):25-39.

2. Wallace DV, Dykewicz MS, Bernstein DI, Blessing-Moore J, Cox L, Khan DA, et al. The diagnosis and management of rhinitis: an updated practice parameter. J Allergy Clin Immunol. 2008; 122(Suppl 2):S1-84.

3. Wallace DV, Dykewicz MS. Seasonal allergic rhinitis. Curr Opin Allergy Clin Immunol. 2017; 17(4):286-94.

4. Novakova SM, Staevska MT, Novakova PI, Yoncheva MD, Bratoycheva MS, Musurlieva NM, et al. Quality of life improvement after a three-year course of sublingual immu- notherapy in patients with house dust mite and grass pollen induced allergic rhinitis: results from real-life. Health Qual Life Outcomes. 2017; 15(1):189.

5. Valls-Mateus $M$, Marino-Sanchez F, Ruiz-Echevarría $K$ Cardenas-Escalante P, Jiménez-Feijoo R, Blasco-Lozano J, et al. Nasal obstructive disorders impair health-related quality of life in adolescents with persistent allergic rhinitis: A real-life study. Pediatr Allergy Immunol. 2017; 28(5):438-45.

6. Camelo-Nunes IC, Solé D. Allergic rhinitis: indicators of quality of life. J Bras Pneumol. 2010; 36(1):124-33.

7. Hoehle LP, Speth MM, Phillips KM, Gaudin RA, Caradonna DS, Gray ST, et al. Association between Symptoms of Allergic Rhinitis with Decreased General Health-Related Quality of Life. Am J Rhinol Allergy. 2017; 31(4):235-9.

8. Mahdavinia M, Schleimer RP, Keshavarzian A. Sleep disruption in chronic rhinosinusitis. Expert Rev Anti Infect Ther. 2017; 15(5):457-65.

9. Meltzer EO, Gross GN, Katial R, Storms WW. Allergic rhinitis substantially impacts patient quality of life: findings from the Nasal Allergy Survey Assessing Limitations. J Fam Pract. 2012; 61(2):S5-10.

10. de la Hoz Caballer B, Rodríguez M, Fraj J, Cerecedo I, Antolín-Amérigo D, Colás C. Allergic rhinitis and its impact on work productivity in primary care practice and a comparison with other common diseases: the Cross-sectional study to Evaluate work Productivity in allergic Rhinitis compared with other common diseases (CAPRI) study. Am J Rhinol Allergy. 2012; 26(5):390-4.

11. Tschopp JM, Sistek D, Schindler C, Leuenberger P, Perruchoud AP, Wüthrich $B$, et al. Current allergic asthma and rhinitis: diagnostic efficiency of three commonly used atopic markers (IgE, skin prick tests, and Phadiatop). Results from 8329 randomized adults from the SAPALDIA Study. Swiss Study on Air Pollution and Lung Diseases in Adults. Allergy. 1998; 53(6):608-13.

12. Juniper EF, Guyatt GH, Griffith LE, Ferrie PJ. Interpretation of rhinoconjunctivitis quality of life questionnaire data. J Allergy Clin Immunol. 1996; 98(4):843-5.

13. Axelsson M, Brink E, Lötvall J. A personality and gender perspective on adherence and health-related quality of life in people with asthma and/or allergic rhinitis. J Am Assoc Nurse Pract. 2014; 26(1):32-9.

14. Li L, Guan K. [Quality of life in 164 allergic rhinitis patients caused by different aeroallergens]. Lin Chung Er Bi Yan Hou Tou Jing Wai Ke Za Zhi. 2015; 29(3):226-9.

15. Meltzer EO, Nathan R, Derebery J, Stang PE, Campbell UB, Yeh W-S, et al. Sleep, quality of life, and productivity impact of nasal symptoms in the United States: findings from the Burden of Rhinitis in America survey. Allergy asthma Proc. 2009; 30(3):244-54.

16. Koinis-Mitchell D, Craig T, Esteban CA, Klein RB. Sleep and allergic disease: a summary of the literature and future directions for research. J Allergy Clin Immunol. 2012; 130(6):1275-81.

17. Izuhara $K$, Nunomura S, Nanri Y, Ogawa M, Ono J, Mitamura Y, et al. Periostin in inflammation and allergy. Cell Mol Life Sci. 2017; 74(23):4293-303.

18. Sha J, Meng C, Li L, Cui N, Xiu Q, Zhu D. Correlation of Serum $\beta$-Endorphin and the Quality of Life in Allergic Rhinitis. Dis Markers. 2016; 2016:2025418.

19. Wang X, Hu G, Kang H, Ke X, Hong S. [Increased IL-19 level in peripheral blood of patients with allergic rhinitis is related with clinical severity]. Xi Bao Yu Fen Zi Mian Yi Xue Za Zhi. 2015; 31(11):1537-40, 1543.

20. American Academy of Allergy Asthma and Immunology. Rhinitis (hay fever) overview. Revised 2019. Available at: https:// www.aaaai.org 